\title{
Geospatial Analysis of Individual and Community-Level Socioeconomic Factors Impacting SARS-CoV-2 Prevalence and Outcomes
}

Running title: Geospatial Analysis of Socioeconomic Factors Impacting SARS-CoV-2 Outcomes

Sara J. Cromer, MD ${ }^{1,2,3 *}$; Chirag M. Lakhani, $\mathrm{PhD}^{2,3 *}$; Deborah J Wexler, MD, MSc ${ }^{1,2}$; Sherri-Ann M. Burnett-Bowie, MD, $\mathrm{MPH}^{2,4}$; Miriam Udler, MD, $\mathrm{PhD}^{1,2,3}$; Chirag J. Patel, $\mathrm{PhD}^{2}$

*Drs. Cromer and Lakhani contributed equally to this manuscript

1. Diabetes Unit, Massachusetts General Hospital, Boston, MA 02114

2. Harvard Medical School, Boston, MA 02115

3. Broad Institute of Harvard and Massachusetts Institute of Technology, Cambridge, MA 02142

4. Endocrine Unit, Massachusetts General Hospital, Boston, MA 02114

Sara J. Cromer, MD

Division of Endocrinology, Diabetes, and Metabolism

Massachusetts General Hospital

scromer@mgh.harvard.edu

Chirag M. Lakhani, PhD

Department of Biomedical Informatics

Harvard Medical School, Boston, MA, USA

chirag_lakhani@hms.harvard.edu

Deborah J. Wexler, MD, MSc

Division of Endocrinology, Diabetes, and Metabolism

Massachusetts General Hospital

dwexler@mgh.harvard.edu

Sherri-Ann M. Burnett-Bowie, MD, MPH

Division of Endocrinology, Diabetes, and Metabolism

Massachusetts General Hospital

sburnett-bowie@mgh.harvard.edu

Miriam Udler, MD, PhD

Division of Endocrinology, Diabetes, and Metabolism

Massachusetts General Hospital

mudler@mgh.harvard.edu

Chirag J. Patel, PhD

Department of Biomedical Informatics

Harvard Medical School, Boston, MA, USA

chirag_patel@hms.harvard.edu

\section{FUNDING}

This work was supported by the National Institutes of Health (grant numbers T32DK007028,

NIDDK T32DK110919) and the National Science Foundation (grant number 1636870). The content is 
medRxiv preprint doi: https://doi.org/10.1101/2020.09.30.20201830; this version posted September 30, 2020. The copyright holder for this preprint (which was not certified by peer review) is the author/funder, who has granted medRxiv a license to display the preprint in perpetuity.

It is made available under a CC-BY 4.0 International license .

solely the responsibility of the authors and does not necessarily represent the views of the National

Institutes of Health.

Abstract word count: 272

Manuscript word count: 3119 
medRxiv preprint doi: https://doi.org/10.1101/2020.09.30.20201830; this version posted September 30, 2020. The copyright holder for this

It is made available under a CC-BY 4.0 International license .

\begin{abstract}
Background: The SARS-CoV-2 pandemic has disproportionately affected racial and ethnic minority communities across the United States. We sought to disentangle individual and census tract-level sociodemographic and economic factors associated with these disparities.

Methods and Findings: All adults tested for SARS-CoV-2 between February 1 and June 21, 2020 were geocoded to a census tract based on their address; hospital employees and individuals with invalid addresses were excluded. Individual (age, sex, race/ethnicity, preferred language, insurance) and census tract-level (demographics, insurance, income, education, employment, occupation, household crowding and occupancy, built home environment, and transportation) variables were analyzed using linear mixed models predicting infection, hospitalization, and death from SARS-CoV-2.
\end{abstract}

Among 57,865 individuals, per capita testing rates, individual (older age, male sex, non-White race, nonEnglish preferred language, and non-private insurance), and census tract-level (increased population density, higher household occupancy, and lower education) measures were associated with likelihood of infection. Among those infected, individual age, sex, race, language, and insurance, and census tract-level measures of lower education, more multi-family homes, and extreme household crowding were associated with increased likelihood of hospitalization, while higher per capita testing rates were associated with decreased likelihood. Only individual-level variables (older age, male sex, Medicare insurance) were associated with increased mortality among those hospitalized.

Conclusions: This study of the first wave of the SARS-CoV-2 pandemic in a major U.S. city presents the cascade of outcomes following SARS-CoV-2 infection within a large, multi-ethnic cohort. SARS-CoV-2 infection and hospitalization rates, but not death rates among those hospitalized, are related to census tract-level socioeconomic characteristics including lower educational attainment and higher household crowding and occupancy, but not neighborhood measures of race, independent of individual factors. 


\section{INTRODUCTION}

As infections with SARS-CoV-2 and its associated illness, COVID-19, have surged across the world, multiple studies have identified higher rates of infection, hospitalization, and mortality among minority populations. ${ }^{1-12}$ Disparities in infection rates exist even among healthcare workers ${ }^{13}$ and children, ${ }^{14,15}$ with disparities in mortality rates greatest among young individuals ${ }^{16}$ and growing as the pandemic spreads. ${ }^{17}$ To date, the relative contributions of pathophysiologic and socioeconomic factors contributing to these disparities remains unclear.

Many studies demonstrate that racial and ethnic minority communities in the U.S. have higher rates of chronic disease,${ }^{18,19}$ which likely contributes to the increased risk of severe illness and death related to SARS-CoV-2 infection seen in these communities. However, social determinants of health likely contribute both to this underlying disparity in chronic disease prevalence, with some claiming that socioeconomic and environmental factors may play an even stronger role in disease than individual factors ${ }^{20}$ and to risk for SARS-CoV-2. This report aims to disentangle the relative contributions of individual and neighborhood sociodemographic and economic factors associated with individual risk.

Many experts in the field of health disparities have authored viewpoints suggesting factors which may contribute to risk of infection with or adverse outcomes from SARS-CoV-2, including language barriers, lower health literacy, higher population density, household overcrowding, reliance on public transit, overrepresentation among essential workers, lack of paid sick leave, inability to work from home, and limited physical and financial access to healthcare. ${ }^{18,21-26}$ However, despite widespread interest in this topic, ${ }^{3-6}$ relatively few studies have reported data examining robust socioeconomic concepts in relationship to SARS-CoV-2 outcomes. Many COVID-19 surveillance studies on this topic do not present individual data, but aggregated outcomes over large and diverse geographic areas (e.g. counties). Those studies which do present individual outcome data have included variable measures of socioeconomic status, and many of these studies are limited by small sample sizes, ethnically homogeneous populations, 
or examination of only a single socioeconomic measure (e.g. income) or SARS-CoV-2-related outcome (e.g. hospitalization, without consideration of the upstream outcome of infection).

Further, many studies capture area-level socioeconomic measures on a county, city/town, or zip code level, which obscures the granular variation in socioeconomic factors over adjacent areas. Census tracts represent geographical units that are smaller in population size than zip codes (average population 4,000 vs 30,000 ) and represent more homogeneous socioeconomic regions, ${ }^{27}$ leading to stronger

associations with health outcomes. ${ }^{28}$ We hypothesized that high resolution geocoding to the census tractlevel would capture more variation in COVID-19 cases and disease trajectory related to sociodemographic and economic factors.

In this study, we examine both individual and census tract-level indicators to identify factors associated with SARS-CoV-2 infection, hospitalization among infected individuals, and death among hospitalized individuals in a large and diverse cohort seeking care within an integrated healthcare system in New England.

\section{METHODS}

\section{DATA SOURCES}

Individual demographics, address, laboratory values, diagnoses, hospitalizations, and deaths were obtained from the electronic medical record (EMR) of Mass General Brigham (MGB, formerly Partners HealthCare), a large, integrated healthcare system serving Eastern Massachusetts. Census tract sociodemographic, economic, and built environment characteristics were obtained from the 2014-2018 American Community Survey (ACS).

\section{STUDY POPULATION}

All individuals who received viral polymerase chain reaction (PCR) testing for SARS-CoV-2 in the MGB system between February 1, 2020 and June 21, 2020, a window beginning approximately two 
months before and ending three months after the peak of the Massachusetts surge, were included. Individual addresses were geocoded to a latitude and longitude (using the DeGAUSS geocoder, ${ }^{29}$ Supplemental Figure 1) from which census tracts were assigned. Individuals were excluded if their address was invalid, unlisted, a PO box number, or located outside Massachusetts; they did not have a valid test result (e.g. test inconclusive); their age was < 18 years; or they were employed by the MGB system (due to different exposures and thresholds for testing compared to the general population).

\section{STUDY OUTCOMES AND COVARIATES}

Outcomes included (1) infection with SARS-CoV-2, (2) hospitalization related to SARS-CoV-2 among those testing positive, and (3) death among those hospitalized (see Figure 1 for population included in each outcomes analysis). SARS-CoV-2 infection was defined by positive PCR testing at an MGB facility. Hospitalizations were considered related to SARS-CoV-2 if a positive test occurred during or up to ten days prior to the inpatient admission or if a positive test occurred outside this window but inpatient encounter ICD10 codes suggested a SARS-CoV-2-related admission (B97.29, Z03.818, or Z20.828, recommended by the CDC prior to the availability of codes specific for SARS-CoV- $2 ;^{30}$ or U07.1, "COVID-19," which became effective as of April 1, 2020). Any death following a related hospitalization was considered SARS-CoV-2-related.

Individual demographic variables included age, sex, race/ethnicity, and preferred language, each obtained by self-report upon registration in the hospital system. Racial and ethnic variables were collapsed into non-Hispanic White, non-Hispanic Black, non-Hispanic Asian, Hispanic, and Other categories, and preferred languages were categorized as English, Spanish, or Other. In patients with selfreported "Other" or missing race, self-reported country of origin and language were used to infer race when available ( $\mathrm{n}=859$ of 4,363; Supplemental Table 1-2). A sensitivity analysis was performed in which only those with missing, and not of "other," race were reassigned based on either country of origin or preferred language. Insurance was categorized as private, non-Medicare (including private health insurance without any Medicare plans), Medicare (including any Medicare plan among listed insurances), 
medRxiv preprint doi: https://doi.org/10.1101/2020.09.30.20201830; this version posted September 30, 2020. The copyright holder for this

It is made available under a CC-BY 4.0 International license .

public (including Medicaid, Mass Health, and other public insurance plans excluding Medicare), and safety net/uninsured (including those with safety net, self-pay, or no insurance listed).

Census tract-level variables included population density and measures of demographics, health insurance, income, education, employment, occupation, household crowding (individuals per room) and occupancy (individuals per household), built home environment (housing units per building), and transportation use, all reported as continuous percentages in ACS data tables (Supplemental Table 3). ACS variables with low variability in our sample (defined as $\geq 75 \%$ of census tracts having the same value) were dichotomized (Supplemental Table 4). Essential workers were classified by applying the U.S. Department of Homeland Security “Advisory Memorandum on Identification of Essential Critical Infrastructure Workers During COVID-19 Response" to ACS Table C24050. Per capita testing rates were calculated as the number of individuals tested in the MGB system living in that census tract divided by the total population of the tract. SARS-CoV-2 positivity rates are reported as the total number of positive individuals divided by the total number of tested individuals in each census tract.

\section{STATISTICAL ANALYSIS}

Baseline characteristics are reported using means and standard deviations for continuous variables and proportions for categorical variables.

All models were fit using a logistic mixed model with a "matern kernel" as a random effect to account for spatial autocorrelation, using latitude and longitude of the address to estimate spatial similarity. ${ }^{31}$ The matern kernel has multiple hyperparameters. For each of the three outcomes (Figure 2a) we used the "base variables" (including all individual-level characteristics and census tract per capita testing rates; Table 1, Figure 2b) to perform a "grid search" to find the range and knot parameters that gave the best model (Figure 2c; the "base models"). We used the same parameters in subsequent analyses. We then fit logistic mixed models using all base variables plus each census tract variable alone (the "base-plus models"). We accounted for multiple hypothesis testing for census tract-level variables in the 
base-plus models using the false discovery rate (FDR) adjustment procedure where an FDR-adjusted pvalue of $<0.05$ was deemed significant (Table 2). Finally, we fit multivariable logistic mixed models with all base variables and all census tract variables which fell under the FDR significance threshold in the base-plus models (the "full models"). For any cluster of similar census variables (e.g. percent of households with $\geq 5$ people, percent of households with $\geq 6$ people) we selected the variable with the lowest p-value to be included in the full model. We exponentiated all coefficients in order to report odds ratio per 1-unit change of each variable (percentage point, year in age, or versus the referent [Tables 1-2]). In the full multivariable model, we assessed significance and independent association using a p-value < 0.05. All analyses were performed using R version 3.6.2.

This study was reviewed and deemed exempt by the Institutional Review Board of Mass General Brigham.

\section{RESULTS}

\section{BASELINE CHARACTERISTICS}

A total of 80,502 individuals were tested for SARS-CoV-2 in the MGB system between February 1, 2020 and June 21, 2020, and 57,865 individuals met inclusion criteria (Figure 1). Of these, 56\% were female, $36 \%$ were of Asian, Black, Hispanic, or Other race/ethnicity (henceforth "non-White" for brevity), and mean age was 52.3 years. Tested individuals resided in 1,386 unique census tracts. Detailed baseline characteristics of tested individuals are presented in Table 1. Census tract characteristics in the Boston area are presented in Figure 3 and Supplemental Figure 1.

\section{INDIVIDUAL AND CENSUS TRACT-LEVEL FACTORS ASSOCIATED WITH SARS-CoV-2 INFECTION}

Of the individuals tested for SARS-CoV-2 infection, 9,839 (17.0\%) tested positive. Census tract per capita testing rates were highly associated with the likelihood of an individual testing positive. All 
medRxiv preprint doi: https://doi.org/10.1101/2020.09.30.20201830; this version posted September 30, 2020. The copyright holder for this

It is made available under a CC-BY 4.0 International license .

individual-level characteristics, including older age, male sex, non-White race, preferred language being other than English, and Medicaid and uninsured/unlisted insurance status, were associated with increased likelihood of infection (Table 2). In the full multivariable models, census tract-level factors, including higher logarithm of population density (OR 1.14, 95\% CI 1.03, 1.27) and increase in the percent with higher household occupancy ( $\geq 5$ individuals per household; OR 2.20, 95\% CI 1.13, 4.30) were associated with risk of infection, while increased percent with a college education (OR $0.63,95 \%$ CI 0.40, 0.99) was associated with lower risk.

\section{INDIVIDUAL AND CENSUS TRACT-LEVEL FACTORS ASSOCIATED WITH HOSPITALIZATION AND DEATH RELATED TO SARS-CoV-2}

Among those who tested positive, 3,009 (30.6\%) required hospitalization related to SARS-CoV-

2. Hospitalization was associated with individual older age; male sex; Black, Asian, or Other race;

Spanish language preference; and Medicare and Medicaid insurance in all models. By contrast, higher per capita testing rates, Hispanic ethnicity, missing race or language, and uninsured/unlisted insurance status associated with lower rates of hospitalization. Census tract-level factors including presence of extreme household crowding (any homes with $\geq 2$ occupants per room vs none; OR 1.14, 95\% CI 1.01, 1.30), higher percent multi-family homes (OR 1.83, 95\% CI 1.01, 3.31), and higher percent of individuals with less than high school education (OR 5.19, 95\% CI 1.15, 23.50) were associated with hospitalization in the full model (Table 2).

Of the individuals hospitalized for SARS-CoV-2, 524 (17.4\%) died. Factors associated with death during the observation period included only individual older age (OR for a 1 year increase $1.06,95 \% \mathrm{CI}$ 1.05, 1.07), male sex (OR 1.64, 95\% CI 1.32, 2.04), and Medicare insurance (OR 1.87 vs private, $95 \%$ CI $1.41,2.49$ ). No census tract-level variables were associated with death in the base-plus models (Table 2). All significant results are summarized in Figure 4. 
medRxiv preprint doi: https://doi.org/10.1101/2020.09.30.20201830; this version posted September 30, 2020. The copyright holder for this

It is made available under a CC-BY 4.0 International license .

\section{DISCUSSION}

This study demonstrates that individual SARS-CoV-2 infection in Eastern Massachusetts was associated with key census tract-level measures of higher population density, percent without a college degree, and household occupancy, independently of individual factors including older age, male sex, nonWhite race, non-English preferred language, and Medicaid or uninsured/unlisted insurance as compared to private insurance. Those infected with SARS-CoV-2 had higher rates of hospitalization if they lived in areas with higher rates of extreme household crowding and percent multi-family homes and lower rates of high school completion. Although census tract-level sociodemographic and economic factors were associated with infection and hospitalization, they were not associated with mortality among those hospitalized. Death was associated only with individual-level factors, including older age, male sex, and Medicare insurance (which may further capture age as a risk factor). Together, these findings suggest that while community socioeconomic factors do increase risk of infection and hospitalization, they are not clearly associated with death among those hospitalized for SARS-CoV-2, as seen in previous studies. ${ }^{7,32}$

Our study identified individual non-English language and census tract-level lower educational attainment as significant risk factors for both infection and hospitalization even after adjustment for race and ethnicity. To our knowledge, this has not been previously described. These findings lend support for efforts to provide easily accessible, multi-lingual educational materials targeted to all educational levels regarding social distancing practices, symptoms of SARS-CoV-2, and known risk factors for adverse outcomes. Further, we were able to refine previous associations between infection and hospitalization rates with area-level household crowding. In fact, this association is consistent with smaller studies ${ }^{33,34}$ and may partially explain racial disparities seen in aggregated county-level data. ${ }^{19}$ For example, approximately one-fifth of US residential units are unsuitable for home quarantine based on the number of rooms available per individual, with racial and ethnic minorities overrepresented among these households. $^{35}$ 
By examining the full spectrum of outcomes from testing to mortality in a very large urban cohort, this study extends the developing body of research suggesting that race/ethnicity, socioeconomic status, and neighborhood factors are significantly and independently associated with risk of both infection with and adverse outcomes due to SARS-CoV-2. Multiple studies have examined aggregated larger arealevel factors associated with infection or death, identifying area-level race, population density, poverty, household crowding, and lower rates of medical insurance as risk factors. ${ }^{19,36,37}$ By contrast, few studies have examined individual-level data to study the relationship between sociodemographic and economic factors in both SARS-CoV-2 infections and outcomes. Studies in the US and UK have identified nonWhite race, higher household crowding and occupancy, lower income, higher unemployment, and employment as essential or healthcare workers as correlates of infection among those tested, ${ }^{15,33,38-40}$ findings which are largely consistent with our analyses. However, these studies have largely examined these socioeconomic measures in isolation, without adjusting for related area-level socioeconomic measures. Similarly, non-White race, household crowding, socioeconomic deprivation indices and lower income, and Medicaid or absent health insurance have been associated with hospitalization or death, ${ }^{7,8,10,34,41,42}$ although it is not clear if these factors would be significant in models adjusted for other socioeconomic factors.

Our study builds on previous findings by leveraging a larger and more diverse cohort, adjusting for numerous census tract-level variables to represent diverse and correlated socioeconomic constructs, and describing the complete cascade of outcomes beginning with SARS-CoV-2 testing and including diagnosis of SARS-CoV-2, hospitalization, and death. This results in the ability to disentangle individual and neighborhood factors contributing to risk (Figure 4a). For instance, area-level measures of percent racial and ethnic minority residents, which were previously associated with SARS-CoV-2 outcomes in studies using aggregated data from our study area, ${ }^{37,40}$ were significant in our base-plus models (models including individual characteristics and a single census tract-level variable, e.g. percent Black residents) of infection and hospitalization; however, these variables lost significance in multivariable models 
medRxiv preprint doi: https://doi.org/10.1101/2020.09.30.20201830; this version posted September 30, 2020. The copyright holder for this

It is made available under a CC-BY 4.0 International license .

adjusting for other census tract-level socioeconomic factors, such as educational attainment and household occupancy, suggesting these were the true factors associated with outcomes, rather than neighborhood racial/ethnic makeup itself. Further, we believe that analysis at the census tract-level, rather than the larger zip code or county levels, allows for improved identification of subtle associations. For example, we detect associations of census-tract educational attainment with infection rates, an association not found in a study of Massachusetts using data at the city or town-level. ${ }^{40}$ We find that individual age, sex, race/ethnicity, language, and insurance associate with both infection and hospitalization, while different census tract-level sociodemographic and economic factors associate with each outcome. However, even in models fully adjusted for significant community socioeconomic factors, the association of individual race/ethnicity with outcomes persists, suggesting that differences in underlying comorbidities or as yet unrecognized environmental contributors to risk may not be captured in this analysis.

One important characteristic in the discussion of disparities in SARS-CoV-2 outcomes bears further discussion. In our sample, Hispanic ethnicity and Spanish language are highly, but not completely, correlated, yet our models showed opposite directions of effect for these variables on hospitalization. To improve our understanding of these factors in isolation, we created base models for hospitalization and death, alternately excluding race/ethnicity or language (Supplemental Table 5). These found no significant association between Hispanic ethnicity or Spanish language and hospitalization or death when the other variable was excluded. On average, Hispanic patients are younger than the overall population, which may drive this neutral association with adverse outcomes despite higher rates of infection.

\section{LIMITATIONS}

These findings must be interpreted in the context of the study design. The number of cases diagnosed depends heavily on testing rates, which were influenced by changing testing criteria which, in turn, were influenced by local government actions, the necessity of ensuring healthcare worker safety, 
prevalence of community health centers conducting outpatient testing, and awareness of existing outbreaks. For this reason, we adjusted all analyses for census tract-level per capita testing rates. Additionally, this cohort included only patients tested within one large healthcare system, leading to under-representation of neighborhoods in this geographic area which are predominantly served by other institutions, raising the possibility of selection bias. Similarly, while we fully capture test positivity among those tested and death among those hospitalized, an individual may have been tested in the MGB system but later presented to another hospital for admission, leading to incomplete capture of the hospitalization outcome. This may be especially common among those with missing information (e.g. insurance) who may have only interacted with the MGB system briefly for a SARS-CoV-2 test. While deaths which occurred in individuals admitted to other hospitals were not captured, these individuals would have been excluded from the death analysis which only included those hospitalized in our system. Although more than 500 deaths occurred in the cohort, power to detect smaller differences related to highly correlated variables may be limited. Race is a social construct influenced by many factors; the prescribed assignment of race based on country of origin and language oversimplifies the concept of race and may lead to misassignment of individuals of mixed ancestry, complex racial identity, or a minority racial identity in their country of origin. However, in a sensitivity analysis in which only those with missing race data, but not self-reported "Other," race were reassigned (n=393 of 3,248, Supplemental Tables 6-7), the effects of individual race on infection risk persisted. Finally, census tract-level indicators are correlated with both individual-level and other census tract-level characteristics, suggesting complex interdependencies between these variables.

\section{CONCLUSIONS}

This study highlights the important impact of sociodemographic and economic factors on risk of SARS-CoV-2 infection, hospitalization, and death and demonstrates a method for studying socioeconomic effects in large healthcare cohorts that considers their complex interplay. These findings 
medRxiv preprint doi: https://doi.org/10.1101/2020.09.30.20201830; this version posted September 30, 2020. The copyright holder for this preprint (which was not certified by peer review) is the author/funder, who has granted medRxiv a license to display the preprint in perpetuity. It is made available under a CC-BY 4.0 International license .

help to explain the racial and ethnic disparities seen during the COVID-19 pandemic as part of a complex milieu of socioeconomic and structural factors which contribute to disease risk. As many countries anticipate second waves of SARS-CoV-2 infection, the findings of this study from the first wave of SARS-CoV-2 in a large urban area may help to identify individuals and communities at greatest risk during subsequent outbreaks. 


\section{AUTHOR CONTRIBUTIONS}

SJC conceived of the study. SJC and CML designed the analysis which was performed by CML. CJP oversaw the analysis. CJP, MU, and DJW provided critical feedback on all analyses. SMB provided critical feedback regarding the use of race or ethnicity in the analysis and the interpretation of the results. SJC drafted the manuscript with critical review provided by all authors.

\section{DISCLOSURES}

A close family member of SJC is employed by a Johnson \& Johnson company. CML is a consultant to XY.health, Inc. DJW reports serving on data monitoring committees for Novo Nordisk. CJP is a cofounder and consultant to XY.health, Inc.

\section{IRB APPROVAL}

This study was reviewed and deemed exempt by the Institutional Review Board of Mass General Brigham. 


\section{Citations}

1. Yancy CW. COVID-19 and African Americans. JAMA. Published online April 15, 2020. doi:10.1001/jama.2020.6548

2. Laurencin CT, McClinton A. The COVID-19 Pandemic: a Call to Action to Identify and Address Racial and Ethnic Disparities. J Racial and Ethnic Health Disparities. Published online April 18, 2020. doi:10.1007/s40615-020-00756-0

3. Reyes C, Nausheen Husain, Christy Gutowski, Stacy St Clair, Gregory Pratt. Chicago's coronavirus disparity: Black Chicagoans are dying at nearly six times the rate of white residents, data show. chicagotribune.com. https://www.chicagotribune.com/coronavirus/ct-coronavirus-chicagocoronavirus-deaths-demographics-lightfoot-20200406-77nlylhiavgjzb2wa4ckivh7mu-story.html. Accessed May 5, 2020.

4. Reis Thebault, Andrew Ba Tran, Vanessa Williams. African Americans are at higher risk of death from coronavirus - The Washington Post. The Washington Post.

https://www.washingtonpost.com/nation/2020/04/07/coronavirus-is-infecting-killing-blackamericans-an-alarmingly-high-rate-post-analysis-shows/?arc404=true. Accessed May 5, 2020.

5. Moore D, Globe Staff U. New study confirms staggering racial disparities in COVID-19 cases in Massachusetts - The Boston Globe. BostonGlobe.com.

https://www.bostonglobe.com/2020/08/27/nation/new-study-finds-staggering-racial-disparitiescovid-19-cases-massachusetts/. Published August 27, 2020. Accessed September 21, 2020.

6. Mays JC, Newman A. Virus Is Twice as Deadly for Black and Latino People Than Whites in N.Y.C. - The New York Times. The New York Times. https://www.nytimes.com/2020/04/08/nyregion/coronavirus-race-deaths.html. Accessed May 5, 2020.

7. Price-Haywood EG, Burton J, Fort D, Seoane L. Hospitalization and Mortality among Black Patients and White Patients with Covid-19. New England Journal of Medicine. 2020;382(26):25342543. doi:10.1056/NEJMsa2011686

8. Killerby ME. Characteristics Associated with Hospitalization Among Patients with COVID-19 Metropolitan Atlanta, Georgia, March-April 2020. MMWR Morb Mortal Wkly Rep. 2020;69. doi:10.15585/mmwr.mm6925e1

9. Wortham JM. Characteristics of Persons Who Died with COVID-19 - United States, February 12May 18, 2020. MMWR Morb Mortal Wkly Rep. 2020;69. doi:10.15585/mmwr.mm6928e1

10. Lobelo F, Bienvenida AX, Leung S, et al. Clinical, Behavioral and Social Factors Associated with Racial Disparities in Hospitalized and Ambulatory COVID-19 Patients from an Integrated Health Care System in Georgia. Infectious Diseases (except HIV/AIDS); 2020. doi:10.1101/2020.07.08.20148973

11. Martinez DA, Hinson JS, Klein EY, et al. SARS-CoV-2 Positivity Rate for Latinos in the Baltimore-Washington, DC Region. JAMA. 2020;324(4):392-395. doi:10.1001/jama.2020.11374 
12. Karaca-Mandic P, Georgiou A, Sen S. Assessment of COVID-19 Hospitalizations by Race/Ethnicity in 12 States. JAMA Intern Med. Published online August 17, 2020. doi:10.1001/jamainternmed.2020.3857

13. Nguyen LH, Drew DA, Graham MS, et al. Risk of COVID-19 among front-line health-care workers and the general community: a prospective cohort study. The Lancet Public Health. Published online July 2020:S246826672030164X. doi:10.1016/S2468-2667(20)30164-X

14. Kim L, Whitaker M, O'Halloran A, et al. Hospitalization Rates and Characteristics of Children Aged <18 Years Hospitalized with Laboratory-Confirmed COVID-19 - COVID-NET, 14 States, March 1-July 25, 2020. MMWR Morb Mortal Wkly Rep. 2020;69(32). doi:10.15585/mmwr.mm6932e3

15. Goyal MK, Simpson JN, Boyle MD, et al. Racial/Ethnic and Socioeconomic Disparities of SARSCoV-2 Infection Among Children. Pediatrics. Published online August 5, 2020:e2020009951. doi:10.1542/peds.2020-009951

16. Reeves TF Sarah Reber, and Richard V. Race gaps in COVID-19 deaths are even bigger than they appear. Brookings. Published June 16, 2020. Accessed July 15, 2020.

https://www.brookings.edu/blog/up-front/2020/06/16/race-gaps-in-covid-19-deaths-are-evenbigger-than-they-appear/

17. Green J, Gu J. The Covid Death Rate in Majority-Black Counties Is Getting Worse.

Bloomberg.com. https://www.bloomberg.com/graphics/2020-coronavirus-death-rate-getting-worseblack-communities/. Accessed July 15, 2020.

18. Hooper MW, Nápoles AM, Pérez-Stable EJ. COVID-19 and Racial/Ethnic Disparities. JAMA. Published online May 11, 2020. doi:10.1001/jama.2020.8598

19. Millett GA, Jones AT, Benkeser D, et al. Assessing differential impacts of COVID-19 on black communities. Annals of Epidemiology. 2020;47:37-44. doi:10.1016/j.annepidem.2020.05.003

20. Iton A, Ross RK. Understanding How Health Happens $\square$ : Your Zip Code is More Important Than Your Genetic Code. In: Public Health Leadership: Strategies for Innovation in Population Health and Social Determinants. Routledge: Taylor \& Francis Group; 2017:67-83. Accessed September 21, 2020. http://zums.ac.ir/files/socialfactors/files/Public_Health_Leadership-

Strategies_for_Innovation_in_Population_Health_and_Social_Determinants-2.pdf\#page=84

21. Khunti K, Singh AK, Pareek M, Hanif W. Is ethnicity linked to incidence or outcomes of covid-19? BMJ. 2020;369. doi:10.1136/bmj.m1548

22. Bibbins-Domingo K. This Time Must Be Different: Disparities During the COVID-19 Pandemic. Ann Intern Med. Published online April 28, 2020. doi:10.7326/M20-2247

23. Vetta Sanders Thompson, PhD. African American Employment and Covid-19: Disparities and Compounding Risks. Washington University in St. Louis; 2020. Accessed May 5, 2020. https://publichealth.wustl.edu/wp-content/uploads/2020/04/AA-Employment-COVID-19-article-byVST-April-2020.pdf 
24. Rader B, Astley CM, Sy KTL, et al. Geographic access to United States SARS-CoV-2 testing sites highlights healthcare disparities and may bias transmission estimates. J Travel Med. doi:10.1093/jtm/taaa076

25. Ross J, Diaz CM, Starrels JL. The Disproportionate Burden of COVID-19 for Immigrants in the Bronx, New York. JAMA Intern Med. Published online May 8, 2020. doi:10.1001/jamainternmed.2020.2131

26. Borjas GJ. Demographic Determinants of Testing Incidence and COVID-19 Infections in New York City Neighborhoods. National Bureau of Economic Research; 2020. doi:10.3386/w26952

27. Krieger N, Waterman P, Chen JT, Soobader M-J, Subramanian SV, Carson R. Zip Code Caveat: Bias Due to Spatiotemporal Mismatches Between Zip Codes and US Census-Defined Geographic Areas-The Public Health Disparities Geocoding Project. Am J Public Health. 2002;92(7):11001102. doi:10.2105/AJPH.92.7.1100

28. Thomas AJ, Group for the MRFIT (MRFIT) R, Eberly LE, et al. ZIP-Code-based versus Tractbased Income Measures as Long-Term Risk-adjusted Mortality Predictors. Am J Epidemiol. 2006;164(6):586-590. doi:10.1093/aje/kwj234

29. Brokamp C, Wolfe C, Lingren T, Harley J, Ryan P. Decentralized and reproducible geocoding and characterization of community and environmental exposures for multisite studies. J Am Med Inform Assoc. 2018;25(3):309-314. doi:10.1093/jamia/ocx128

30. ICD-10-CM Official Coding Guidelines - Supplement Coding encounters related to COVID-19 Coronavirus Outbreak. Accessed May 11, 2020. https://www.cdc.gov/nchs/data/icd/ICD-10-CMOfficial-Coding-Gudance-Interim-Advice-coronavirus-feb-20-2020.pdf

31. Wood SN. Fast stable restricted maximum likelihood and marginal likelihood estimation of semiparametric generalized linear models. Journal of the Royal Statistical Society: Series B (Statistical Methodology). 2011;73(1):3-36. doi:10.1111/j.1467-9868.2010.00749.x

32. Yehia BR, Winegar A, Fogel R, et al. Association of Race With Mortality Among Patients Hospitalized With Coronavirus Disease 2019 (COVID-19) at 92 US Hospitals. JAMA Netw Open. 2020;3(8):e2018039-e2018039. doi:10.1001/jamanetworkopen.2020.18039

33. Emeruwa UN, Ona S, Shaman JL, et al. Associations Between Built Environment, Neighborhood Socioeconomic Status, and SARS-CoV-2 Infection Among Pregnant Women in New York City. JAMA. Published online June 18, 2020. doi:10.1001/jama.2020.11370

34. Lassale C, Gaye B, Hamer M, Gale CR, Batty GD. Ethnic disparities in hospitalisation for COVID19 in England: The role of socioeconomic factors, mental health, and inflammatory and proinflammatory factors in a community-based cohort study. Brain Behav Immun. Published online June 1, 2020. doi:10.1016/j.bbi.2020.05.074

35. Sehgal AR, Himmelstein DU, Woolhandler S. Feasibility of Separate Rooms for Home Isolation and Quarantine for COVID-19 in the United States. Annals of Internal Medicine. Published online July 21, 2020. doi:10.7326/M20-4331

36. Notari A, Torrieri G. COVID-19 transmission risk factors. medRxiv. doi:10.1101/2020.05.08.20095083 
37. Chen JT, Waterman PD, Krieger N. COVID-19 and the unequal surge in mortality rates in Massachusetts, by city/town and ZIP Code measures of poverty, household crowding, race/ethnicity, and racialized economic segregation. Harvard Center for Population and Development Studies Working Paper Series. 2020;19(2).

38. Martin CA, Jenkins DR, Minhas JS, et al. Socio-demographic heterogeneity in the prevalence of COVID-19 during lockdown is associated with ethnicity and household size: Results from an observational cohort study. EClinicalMedicine. 2020;0(0). doi:10.1016/j.eclinm.2020.100466

39. Allen WE, Altae-Tran H, Briggs J, et al. Population-Scale Longitudinal Mapping of COVID-19 Symptoms, Behavior, and Testing Identifies Contributors to Continued Disease Spread in the United States. Epidemiology; 2020. doi:10.1101/2020.06.09.20126813

40. Figueroa JF, Wadhera RK, Lee D, Yeh RW, Sommers BD. Community-Level Factors Associated With Racial And Ethnic Disparities In COVID-19 Rates In Massachusetts. Health Affairs. Published online August 27, 2020:10.1377/hlthaff.2020.01040. doi:10.1377/hlthaff.2020.01040

41. Patel AP, Paranjpe MD, Kathiresan NP, Rivas MA, Khera AV. Race, socioeconomic deprivation, and hospitalization for COVID-19 in English participants of a national biobank. Int J Equity Health. 2020;19. doi:10.1186/s12939-020-01227-y

42. Azar KMJ, Shen Z, Romanelli RJ, et al. Disparities In Outcomes Among COVID-19 Patients In A Large Health Care System In California. Health Affairs. 2020;39(7):1253-1262. doi:10.1377/hlthaff.2020.00598 
Figure 1: Flow diagram of individuals included in analyses of SARS-CoV-2 infection, hospitalization, and death.

Figure 2: Analysis Flow Chart. FDR = False discovery rate.

Figure 3: Map depicting the number of individuals per 1,000 population (A) who tested positive for SARS-CoV-2 in the MGB system in Massachusetts and (B) in the Boston area, (C) who were hospitalized at an MGB facility related to SARS-CoV-2, and (D) who died after their hospitalization. Census tracts with fewer than 5 individuals tested are excluded. Only patients tested within the MGB system are represented.

Figure 4: (A) Conceptual model of an individual's aggregate risk of disease, arising from the interaction between individual and census tract-level risk factors, with red indicating a positive association with adverse outcomes (increased risk) and green indicating a negative association (decreased risk), and (B) summary of individual characteristics (left) and census tract-level concepts (right) which were independently associated with infection with SARS-CoV-2, hospitalization among those infected, and death among those hospitalized within our study sample, with red indicating a positive association with adverse outcomes (increased risk) and green indicating a negative association (decreased risk). HS = high school. 
medRxiv preprint doi: https://doi.org/10.1101/2020.09.30.20201830; this version posted September 30, 2020. The copyright holder for this preprint (which was not certified by peer review) is the author/funder, who has granted medRxiv a license to display the preprint in perpetuity.

It is made available under a CC-BY 4.0 International license .

Table 1: Baseline Characteristics of Individuals Included in the Analysis for Each Outcome, Demonstrating the Cascade of COVID-19 Care.

\begin{tabular}{|c|c|c|c|c|}
\hline Age, mean (SD) & $\begin{array}{l}\text { Total Tested }^{\mathrm{a}} \\
(\mathrm{n}=57,865) \\
52.32(19.31)\end{array}$ & $\begin{array}{c}\text { Any Positive } \\
\text { Test }^{\mathrm{b}} \\
(\mathrm{n}=9,839 \\
17.0 \%) \\
51.23(19.89)\end{array}$ & $\begin{array}{l}\text { Hospitalized, given } \\
\text { positive test }^{\mathrm{b}} \\
(\mathrm{n}=3,009,30.6 \%) \\
62.7(18.90)\end{array}$ & $\begin{array}{c}\begin{array}{c}\text { Deceased, given } \\
\text { hospitalization }^{b}\end{array} \\
(\mathrm{n}=524,17.4 \%) \\
77.05(13.42)\end{array}$ \\
\hline \multicolumn{5}{|l|}{ Age Groups, n (\%) } \\
\hline $18-49$ years & $25,877(44.72)$ & $4,827(18.65)$ & $752(15.58)$ & $19(2.53)$ \\
\hline 50-64 years & $15,041(25.99)$ & $2,475(16.46)$ & $784(31.68)$ & $73(9.31)$ \\
\hline $65-79$ years & $11,837(20.46)$ & $1,479(12.49)$ & $813(54.97)$ & $176(21.65)$ \\
\hline$\geq 80$ years & $5,110(8.83)$ & $1,058(20.70)$ & $660(62.38)$ & $256(38.79)$ \\
\hline \multicolumn{5}{|l|}{ Sex, n (\%) } \\
\hline Female & $32,260(55.75)$ & $4,966(15.39)$ & $1,396(28.11)$ & $224(16.05)$ \\
\hline Male & $25,586(44.22)$ & $4,871(19.04)$ & $1,613(33.11)$ & $300(18.60)$ \\
\hline \multicolumn{5}{|l|}{ Race/Ethnicity, n $(\%)^{\mathrm{c}}$} \\
\hline White, non-Hispanic & $34,398(59.45)$ & $3,235(9.40)$ & $1,307(40.40)$ & $320(24.48)$ \\
\hline Black, non-Hispanic & $5,528(9.55)$ & $1,239(22.41)$ & $468(37.77)$ & $72(15.38)$ \\
\hline Asian, non-Hispanic & $2,077(3.59)$ & $298(14.35)$ & $119(39.93)$ & $16(13.45)$ \\
\hline Hispanic & $12,358(21.36)$ & $4,257(34.45)$ & $985(23.14)$ & $94(9.54)$ \\
\hline Other & $649(1.12)$ & $112(17.26)$ & $39(34.82)$ & $4(10.26)$ \\
\hline Missing & $2,855(4.93)$ & $698(24.45)$ & $91(13.04)$ & $18(19.78)$ \\
\hline \multicolumn{5}{|l|}{ Language, $\mathrm{n}(\%)$} \\
\hline English & $4,6086(79.64)$ & $5,403(11.72)$ & $1,855(34.33)$ & $369(19.89)$ \\
\hline Spanish & $7,602(13.14)$ & $3,289(43.26)$ & $824(25.05)$ & $77(9.34)$ \\
\hline Other & $2,118(3.66)$ & $591(27.90)$ & $279(47.21)$ & $69(24.73)$ \\
\hline Missing & $2,059(3.56)$ & $556(27.00)$ & $51(9.17)$ & $9(17.65)$ \\
\hline \multicolumn{5}{|l|}{ Insurance, $\mathrm{n}(\%)$} \\
\hline Private, non-Medicare & $29,740(51.40)$ & $4,031(13.55)$ & $935(23.20)$ & 85 (9.09) \\
\hline Medicare & $16,480(28.48)$ & $2,311(14.02)$ & $1,365(59.07)$ & $400(29.30)$ \\
\hline Medicaid, MassHealth & $8,397(14.51)$ & $2,435(29.00)$ & $630(25.87)$ & $36(5.71)$ \\
\hline Safety Net/Unlisted & $3,248(5.61)$ & $1,062(32.70)$ & $79(7.44)$ & $3(3.80)$ \\
\hline
\end{tabular}

${ }^{a}$ Percentages represent the percent of individuals tested who fell into a category. (e.g. $44.22 \%$ of all individuals tested were male).

${ }^{\mathrm{b}}$ Percentages represent the percent of individuals experiencing that outcome, among all eligible to experience the outcome in that cell (e.g. 19.04\% of men tested for SARS-CoV-2 received a positive test result).

${ }^{\mathrm{c}}$ Includes reassigned race (based on country of origin or language) for those with recorded Other or Missing race. 


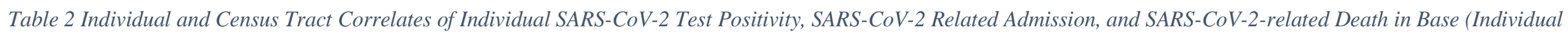
Characteristics only), Base-Plus (Base Model Covariates plus Single Census Tract-Level Variables), and Final Multivariable Models

\begin{tabular}{|c|c|c|c|c|c|c|c|c|c|}
\hline \multirow[b]{2}{*}{$\begin{array}{l}\text { Number of individuals in } \\
\text { analysis, } n \\
\text { Individual Characteristics }\end{array}$} & \multicolumn{3}{|c|}{ SARS-CoV-2 Infection } & \multicolumn{3}{|c|}{ SARS-CoV-2-related Hospitalization } & \multicolumn{3}{|c|}{ SARS-CoV-2-related Mortality } \\
\hline & \multicolumn{3}{|c|}{57,865} & \multicolumn{3}{|c|}{9,839} & \multicolumn{3}{|c|}{3,009} \\
\hline Age & $\begin{array}{c}1.01(1.01 \\
1.01) \\
\end{array}$ & & $\begin{array}{c}1.01(1.01 \\
1.01)\end{array}$ & $\begin{array}{c}1.04(1.04, \\
1.04)\end{array}$ & & $\begin{array}{c}1.04(1.04 \\
1.04)\end{array}$ & $\begin{array}{c}1.06(1.05 \\
1.07) \\
\end{array}$ & & $\begin{array}{c}1.06(1.05 \\
1.07) \\
\end{array}$ \\
\hline Female & Ref & & Ref & Ref & & Ref & Ref & & Ref \\
\hline Male & $\begin{array}{c}1.30(1.24 \\
1.37)\end{array}$ & & $\begin{array}{c}1.30(1.24 \\
1.37)\end{array}$ & $\begin{array}{c}1.50(1.36 \\
1.66)\end{array}$ & & $\begin{array}{c}1.50(1.36 \\
1.66)\end{array}$ & $\begin{array}{c}1.64(1.32 \\
2.04)\end{array}$ & & $\begin{array}{c}1.64(1.32 \\
2.04)\end{array}$ \\
\hline \multicolumn{10}{|l|}{ Race/Ethnicity $^{\mathrm{d}}$} \\
\hline White, non-Hispanic & Ref & & Ref & Ref & & Ref & Ref & & Ref \\
\hline Black, non-Hispanic & $\begin{array}{c}2.72(2.50 \\
2.95)\end{array}$ & & $\begin{array}{c}2.62(2.41 \\
2.86)\end{array}$ & $\begin{array}{c}1.47(1.23 \\
1.74)\end{array}$ & & $\begin{array}{c}1.39(1.16 \\
1.65)\end{array}$ & $\begin{array}{c}0.81(0.57 \\
1.14)\end{array}$ & & $\begin{array}{c}0.81(0.57 \\
1.14)\end{array}$ \\
\hline Hispanic & $\begin{array}{c}2.26(2.07 \\
2.46)\end{array}$ & Model & $\begin{array}{c}2.20(2.02 \\
2.40)\end{array}$ & $\begin{array}{c}0.81(0.66 \\
0.99)\end{array}$ & Model & $\begin{array}{c}0.77(0.63 \\
0.94)\end{array}$ & $\begin{array}{c}1.38(0.80 \\
2.36)\end{array}$ & Model & $\begin{array}{c}1.38(0.80 \\
2.36)\end{array}$ \\
\hline Other & $\begin{array}{c}1.84(1.49 \\
2.28)\end{array}$ & Plus & $\begin{array}{c}1.82(1.47 \\
2.25)\end{array}$ & $\begin{array}{l}1.59(1.01 \\
2.52)\end{array}$ & Plus & $\begin{array}{c}1.53(0.97 \\
2.42)\end{array}$ & $\begin{array}{c}0.43(0.14 \\
1.34)\end{array}$ & Plus & $\begin{array}{c}0.43(0.14 \\
1.34)\end{array}$ \\
\hline Missing & $\begin{array}{c}2.17(1.88, \\
2.49)\end{array}$ & Single & $\begin{array}{c}2.14(1.86, \\
2.46)\end{array}$ & $\begin{array}{c}0.70(0.50, \\
0.97)\end{array}$ & Single & $\begin{array}{c}0.68(0.49 \\
0.95)\end{array}$ & $\begin{array}{c}1.05(0.55 \\
2.00)\end{array}$ & Single & $\begin{array}{c}1.05(0.55 \\
2.00)\end{array}$ \\
\hline Language, $\mathrm{n}(\%)$ & \multicolumn{3}{|c|}{ Census } & \multicolumn{3}{|c|}{ Census } & \multicolumn{3}{|c|}{ Census } \\
\hline English & Ref & Tract-Level & Ref & Ref & Tract-Level & Ref & Ref & Tract-Level & Ref \\
\hline Spanish & $\begin{array}{c}2.37(2.18 \\
2.58)\end{array}$ & Variables & $\begin{array}{c}2.35(2.15 \\
2.56)\end{array}$ & $\begin{array}{c}1.27(1.05 \\
1.54)\end{array}$ & Variables & $\begin{array}{c}1.25(1.03 \\
1.52)\end{array}$ & $\begin{array}{c}0.62(0.35 \\
1.09)\end{array}$ & Variables & $\begin{array}{c}0.62(0.35 \\
1.09)\end{array}$ \\
\hline Other & $\begin{array}{c}1.94(1.74 \\
2.16)\end{array}$ & Below & $\begin{array}{c}1.91(1.71 \\
2.13)\end{array}$ & $\begin{array}{c}1.22(0.98 \\
1.51)\end{array}$ & Below & $\begin{array}{c}1.19(0.96 \\
1.47)\end{array}$ & $\begin{array}{c}1.26(0.87 \\
1.84)\end{array}$ & Below & $\begin{array}{c}1.26(0.87 \\
1.84)\end{array}$ \\
\hline Missing & $\begin{array}{c}1.64(1.41 \\
1.92) \\
\end{array}$ & & $\begin{array}{c}1.63(1.40, \\
1.91)\end{array}$ & $\begin{array}{c}0.43(0.29 \\
0.64) \\
\end{array}$ & & $\begin{array}{c}0.42(0.28 \\
0.63) \\
\end{array}$ & $\begin{array}{c}1.17(0.48, \\
2.85)\end{array}$ & & $\begin{array}{c}1.17(0.48 \\
2.85) \\
\end{array}$ \\
\hline
\end{tabular}




\begin{tabular}{|c|c|c|c|c|c|c|c|c|c|}
\hline & \multicolumn{3}{|c|}{ SARS-CoV-2 Infection } & \multicolumn{3}{|c|}{ SARS-CoV-2-related Hospitalization } & \multicolumn{3}{|c|}{ SARS-CoV-2-related Mortality } \\
\hline & Base Model $^{\mathrm{a}}$ & $\begin{array}{l}\text { Base-Plus } \\
\text { Models }\end{array}$ & Full Model $^{\mathrm{c}}$ & Base Model $^{\mathrm{a}}$ & $\begin{array}{l}\text { Base-Plus } \\
\text { Models }\end{array}$ & Full Model ${ }^{\mathrm{c}}$ & Base Model $^{\mathrm{a}}$ & $\begin{array}{l}\text { Base-Plus } \\
\text { Models }\end{array}$ & Full Model $^{\mathrm{c}}$ \\
\hline \multicolumn{10}{|l|}{ Insurance, $\mathrm{n}(\%)$} \\
\hline Private, non-Medicare & Ref & & Ref & Ref & & Ref & Ref & & Ref \\
\hline Medicare & $\begin{array}{l}0.95(0.88 \\
1.02)\end{array}$ & & $\begin{array}{l}0.94(0.88 \\
1.01)\end{array}$ & $\begin{array}{l}2.22(1.93 \\
2.56)\end{array}$ & & $\begin{array}{l}2.20(1.92 \\
2.54)\end{array}$ & $\begin{array}{l}1.87(1.41, \\
2.49)\end{array}$ & & $\begin{array}{l}1.87(1.41 \\
2.49)\end{array}$ \\
\hline Medicaid, MassHealth & $\begin{array}{l}1.21(1.13 \\
1.30)\end{array}$ & & $\begin{array}{l}1.21(1.13 \\
1.29)\end{array}$ & $\begin{array}{l}1.59(1.38 \\
1.82)\end{array}$ & & $\begin{array}{l}1.57(1.37 \\
1.81)\end{array}$ & $\begin{array}{l}1.02(0.65 \\
1.58)\end{array}$ & & $\begin{array}{c}1.02(0.65 \\
1.58)\end{array}$ \\
\hline Safety Net/Unlisted & $\begin{array}{l}1.25(1.14 \\
1.37)\end{array}$ & & $\begin{array}{c}1.24(1.13 \\
1.37)\end{array}$ & $\begin{array}{l}0.36(0.28 \\
0.47)\end{array}$ & & $\begin{array}{c}0.36(0.28 \\
0.47)\end{array}$ & $\begin{array}{l}0.71(0.21 \\
2.39)\end{array}$ & & $\begin{array}{l}0.71(0.21 \\
2.39)\end{array}$ \\
\hline \multicolumn{10}{|l|}{$\begin{array}{l}\text { Census Tract } \\
\text { Characteristics }\end{array}$} \\
\hline Per Capita Testing Rate & $\begin{array}{c}2262.11 \\
(259.09, \\
19750.08)\end{array}$ & & $\begin{array}{c}1288.28 \\
(125.72 \\
13201.02)\end{array}$ & $\begin{array}{l}0.00(0.00 \\
0.29)\end{array}$ & & $\begin{array}{l}0.00(0.00 \\
\quad 0.03)\end{array}$ & $\begin{array}{c}0.39(0.00 \\
296.76)\end{array}$ & & $\begin{array}{l}0.39(0.00 \\
296.76)\end{array}$ \\
\hline Percent age $\geq 65$ & & $\begin{array}{c}0.78(0.43 \\
1.44)\end{array}$ & & & $\begin{array}{l}0.63(0.18 \\
2.23)\end{array}$ & & & $\begin{array}{l}0.82(0.12 \\
5.81)\end{array}$ & \\
\hline \multicolumn{10}{|l|}{ Race/Ethnicity, mean (IQR) } \\
\hline$\%$ White, non-Hispanic & & $\begin{array}{l}0.60(0.49 \\
0.74)\end{array}$ & & & $\begin{array}{l}0.73(0.48 \\
1.12)\end{array}$ & & & $\begin{array}{l}0.55(0.31 \\
1.00)\end{array}$ & \\
\hline$\%$ Black, non-Hispanic & & $\begin{array}{l}2.21(1.51 \\
3.23)\end{array}$ & $\begin{array}{l}1.53(0.96 \\
2.46)\end{array}$ & & $\begin{array}{l}0.68(0.32 \\
1.43)\end{array}$ & & & $\begin{array}{l}1.51(0.58 \\
3.92)\end{array}$ & \\
\hline$\%$ Asian, non-Hispanic & & $\begin{array}{l}0.95(0.58 \\
1.58)\end{array}$ & $\begin{array}{c}1.11(0.69 \\
1.79)\end{array}$ & & $\begin{array}{l}1.19(0.42 \\
3.37)\end{array}$ & & & $\begin{array}{l}1.46(0.26 \\
8.27)\end{array}$ & \\
\hline$\%$ Hispanic & & $\begin{array}{c}1.67(1.22 \\
2.29)\end{array}$ & $\begin{array}{l}1.30(0.83 \\
2.04)\end{array}$ & & $\begin{array}{c}2.29(1.23 \\
4.26)\end{array}$ & $\begin{array}{c}0.73(0.31 \\
1.75)\end{array}$ & & $\begin{array}{l}1.98(0.78 \\
5.01)\end{array}$ & \\
\hline$\%$ Foreign-born & & $\begin{array}{l}1.99(1.41 \\
2.81)\end{array}$ & $\begin{array}{c}0.80(0.36 \\
1.76)\end{array}$ & & $\begin{array}{l}3.47(1.74, \\
6.92)\end{array}$ & $\begin{array}{c}1.43(0.58 \\
3.48)\end{array}$ & & $\begin{array}{l}1.44(0.49 \\
4.23)\end{array}$ & \\
\hline \multicolumn{10}{|l|}{ Insurance } \\
\hline$\%$ Private, non-Medicare & & $\begin{array}{l}0.66(0.51 \\
0.85)\end{array}$ & $\begin{array}{c}0.80(0.36 \\
1.76)\end{array}$ & & $\begin{array}{l}0.53(0.32 \\
0.88)\end{array}$ & & & $\begin{array}{l}0.51(0.23 \\
1.15)\end{array}$ & \\
\hline$\%$ Medicare & & $\begin{array}{c}0.68(0.34 \\
1.38)\end{array}$ & & & $\begin{array}{l}0.96(0.22 \\
\quad 4.18)\end{array}$ & & & $\begin{array}{c}0.59(0.05 \\
6.45)\end{array}$ & \\
\hline$\%$ Medicaid, MassHealth & & $\begin{array}{l}1.50(1.14 \\
1.98)\end{array}$ & $\begin{array}{c}0.50(0.22 \\
1.15)\end{array}$ & & $\begin{array}{c}1.58(0.90 \\
2.76)\end{array}$ & & & $\begin{array}{c}1.75(0.71 \\
4.29)\end{array}$ & \\
\hline$\%$ Safety Net/None & & $\begin{array}{l}33.50(0.00 \\
2.20 \mathrm{E} 7)\end{array}$ & & & $\begin{array}{c}1438.03(0.00, \\
3.59 \mathrm{E} 15)\end{array}$ & & & $\begin{array}{c}599647228.33 \\
(0.00 \\
1.15 \mathrm{E} 29)\end{array}$ & \\
\hline $\begin{array}{l}\% \text { Safety Net/None, } \\
\text { dichotomized }\end{array}$ & & $\begin{array}{l}0.99(0.92 \\
1.06)\end{array}$ & & & $\begin{array}{c}1.01(0.88 \\
1.17)\end{array}$ & & & $\begin{array}{c}1.10(0.82 \\
1.47)\end{array}$ & \\
\hline
\end{tabular}




\begin{tabular}{|c|c|c|c|c|c|c|c|c|c|}
\hline & \multicolumn{3}{|c|}{ SARS-CoV-2 Infection } & \multicolumn{3}{|c|}{ SARS-CoV-2-related Hospitalization } & \multicolumn{3}{|c|}{ SARS-CoV-2-related Mortality } \\
\hline & Base Model $^{\mathrm{a}}$ & $\begin{array}{l}\text { Base-Plus } \\
\text { Models }\end{array}$ & Full Model $^{\mathrm{c}}$ & Base Model $^{\mathrm{a}}$ & $\begin{array}{l}\text { Base-Plus } \\
\text { Models }\end{array}$ & Full Model $^{\mathrm{c}}$ & Base Model $^{\mathrm{a}}$ & $\begin{array}{l}\text { Base-Plus } \\
\text { Models }\end{array}$ & Full Model $^{\mathrm{c}}$ \\
\hline \multicolumn{10}{|l|}{$\begin{array}{l}\text { Population and Population } \\
\text { Density }\end{array}$} \\
\hline Log (Total Population) & & $\begin{array}{l}0.90(0.74 \\
1.09)\end{array}$ & & & $\begin{array}{l}0.90(0.60 \\
1.34)\end{array}$ & & & $\begin{array}{c}1.74(0.81 \\
3.73)\end{array}$ & \\
\hline Log (Population Density) & & $\begin{array}{c}1.24(1.14, \\
1.36)\end{array}$ & $\begin{array}{c}1.14(1.03 \\
1.27)\end{array}$ & & $\begin{array}{l}1.25(1.04 \\
1.51)\end{array}$ & $\begin{array}{l}0.99(0.80 \\
1.24)\end{array}$ & & $\begin{array}{c}1.14(0.86, \\
1.51)\end{array}$ & \\
\hline \multicolumn{10}{|l|}{$\begin{array}{l}\text { Income and Income } \\
\text { Inequality }\end{array}$} \\
\hline & & $\begin{array}{l}0.44(0.14 \\
1.37)\end{array}$ & & & $\begin{array}{l}0.04(0.00 \\
0.38)\end{array}$ & $\begin{array}{c}1.29(0.02 \\
107.59)\end{array}$ & & $\begin{array}{l}0.05(0.00 \\
1.33)\end{array}$ & \\
\hline $\begin{array}{l}\% \text { public assistance } \\
\text { income }\end{array}$ & & & & & & & & & \\
\hline GINI Index & & $\begin{array}{c}0.96(0.56 \\
1.66) \\
\end{array}$ & & & $\begin{array}{c}0.57(0.18 \\
1.81) \\
\end{array}$ & & & $\begin{array}{c}1.22(0.16 \\
9.45)\end{array}$ & \\
\hline \multicolumn{10}{|l|}{ Poverty } \\
\hline $\begin{array}{l}\% \text { living below } 100 \% \\
\text { federal poverty level }\end{array}$ & & $\begin{array}{c}1.13(0.75 \\
1.69)\end{array}$ & & & $\begin{array}{l}1.70(0.75 \\
3.86)\end{array}$ & & & $\begin{array}{l}1.59(0.40 \\
6.31)\end{array}$ & \\
\hline $\begin{array}{l}\% \text { living below } 150 \% \\
\text { federal poverty level }\end{array}$ & & & & & $\begin{array}{c}1.76(0.94 \\
3.31)\end{array}$ & & & $\begin{array}{l}1.81(0.64 \\
5.16)\end{array}$ & \\
\hline $\begin{array}{l}\% \text { living below } 200 \% \\
\text { federal poverty level }\end{array}$ & & $\begin{array}{c}1.29(0.99 \\
1.69)\end{array}$ & & & $\begin{array}{l}2.07(1.20 \\
\quad 3.55)\end{array}$ & $\begin{array}{c}0.63(0.26 \\
1.54)\end{array}$ & & $\begin{array}{c}1.85(0.76 \\
4.51)\end{array}$ & \\
\hline \multicolumn{10}{|l|}{ Education } \\
\hline $\begin{array}{l}\% \text { without high school } \\
\text { diploma }\end{array}$ & & $\begin{array}{l}2.64(1.69, \\
\quad 4.14)\end{array}$ & $\begin{array}{l}1.39(0.67 \\
2.91)\end{array}$ & & $\begin{array}{l}6.28(2.55 \\
15.49)\end{array}$ & $\begin{array}{l}5.19(1.15 \\
23.50)\end{array}$ & & $\begin{array}{c}1.82(0.41 \\
8.03)\end{array}$ & \\
\hline$\%$ with college degree & & $\begin{array}{c}0.60(0.47 \\
0.76) \\
\end{array}$ & $\begin{array}{c}0.63(0.40 \\
0.99)\end{array}$ & & $\begin{array}{c}0.52(0.33 \\
0.83)\end{array}$ & $\begin{array}{c}0.84(0.36 \\
1.92)\end{array}$ & & $\begin{array}{c}0.60(0.32 \\
1.13)\end{array}$ & \\
\hline \multicolumn{10}{|l|}{ Employment and Occupation } \\
\hline$\%$ unemployed & & $\begin{array}{l}7.58(1.78 \\
32.32)\end{array}$ & $\begin{array}{l}2.82(0.59 \\
13.52)\end{array}$ & & $\begin{array}{l}10.35(0.50 \\
215.08)\end{array}$ & & & $\begin{array}{l}2.88(0.01, \\
965.45)\end{array}$ & \\
\hline$\%$ essential workers & & $\begin{array}{l}1.56(1.15 \\
2.12) \\
\end{array}$ & $\begin{array}{c}0.70(0.43 \\
1.13)\end{array}$ & & $\begin{array}{l}2.19(1.20 \\
\quad 4.02)\end{array}$ & & & $\begin{array}{c}1.45(0.59, \\
3.58)\end{array}$ & \\
\hline
\end{tabular}




\begin{tabular}{|c|c|c|c|c|c|c|c|c|c|}
\hline & \multicolumn{3}{|c|}{ SARS-CoV-2 Infection } & \multicolumn{3}{|c|}{ SARS-CoV-2-related Hospitalization } & \multicolumn{3}{|c|}{ SARS-CoV-2-related Mortality } \\
\hline & Base Model $^{\mathrm{a}}$ & $\begin{array}{c}\text { Base-Plus } \\
\text { Models }\end{array}$ & Full Model $^{\mathrm{c}}$ & Base Model $^{\mathrm{a}}$ & $\begin{array}{l}\text { Base-Plus } \\
\text { Models }^{\mathrm{b}}\end{array}$ & Full Model $^{\mathrm{c}}$ & Base Model $^{\mathrm{a}}$ & $\begin{array}{c}\text { Base-Plus } \\
\text { Models }\end{array}$ & Full Model $^{\mathrm{c}}$ \\
\hline $\begin{array}{l}\text { Household Crowding } \\
\% \text { with }>1 \text { occupant per } \\
\text { room } \\
\% \text { with }>1.5 \text { occupants } \\
\text { per room } \\
\% \text { with }>2 \text { occupants per } \\
\text { room } \\
\% \text { with }>2 \text { occupants per } \\
\text { room, dichotomized }\end{array}$ & & $\begin{array}{c}2.95(1.08 \\
8.08) \\
2.91(0.32 \\
26.83) \\
2.49(0.07 \\
84.40) \\
1.00(0.94 \\
1.07)\end{array}$ & & & $\begin{array}{c}8.89(1.18 \\
67.10) \\
6.88(0.08 \\
578.34) \\
11980.64 \\
(8.68,1.65 \mathrm{E} 7) \\
\mathbf{1 . 1 6}(\mathbf{1 . 0 2} \\
\mathbf{1 . 3 2})\end{array}$ & $\begin{array}{c}1.14(1.01 \\
1.30)\end{array}$ & & $\begin{array}{c}12.65(0.25, \\
632.77) \\
157.80(0.02, \\
1628070.04) \\
0.11(0.00, \\
2.05 \mathrm{E} 6) \\
0.95(0.73, \\
1.24)\end{array}$ & \\
\hline $\begin{array}{l}\text { Household Occupancy } \\
\% \text { households with } \geq 2 \\
\text { members } \\
\% \text { households with } \geq 3 \\
\text { members } \\
\% \text { households with } \geq 4 \\
\text { members } \\
\% \text { households with } \geq 5 \\
\text { members } \\
\% \text { households with } \geq 6 \\
\text { members } \\
\% \text { households with } \geq 7 \\
\text { members }\end{array}$ & & $\begin{array}{c}1.24(0.90, \\
1.71) \\
\mathbf{1 . 5 4}(\mathbf{1 . 1 5}, \\
\mathbf{2 . 0 5 )} \\
\mathbf{1 . 7 2}(\mathbf{1 . 2 0}, \\
\mathbf{2 . 4 7 )} \\
\mathbf{3 . 1 3}(\mathbf{1 . 7 2}, \\
\mathbf{5 . 7 2}) \\
3.36(1.12, \\
10.10) \\
5.28(0.74, \\
37.49) \\
\end{array}$ & $\begin{array}{c}2.20(1.13 \\
4.30)\end{array}$ & & $\begin{array}{c}0.73(0.38, \\
1.40) \\
0.95(0.53, \\
1.70) \\
0.70(0.33, \\
1.45) \\
0.92(0.27 \\
3.08) \\
13.29(1.53, \\
115.08) \\
32.06(0.61, \\
1697.21)\end{array}$ & & & $\begin{array}{c}0.85(0.28 \\
2.59) \\
0.81(0.28 \\
2.35) \\
0.87(0.23 \\
3.34) \\
1.74(0.17 \\
18.02) \\
9.88(0.15 \\
630.50) \\
8.07(0.00 \\
23380.62) \\
\end{array}$ & \\
\hline \multicolumn{10}{|l|}{ Housing Factors } \\
\hline $\begin{array}{l}\text { Median Home Value } \\
\% \text { housing units lacking } \\
\text { plumbing facilities }\end{array}$ & & $\begin{array}{c}0.88(0.71 \\
1.10) \\
2.65(0.92 \\
7.68)\end{array}$ & & & $\begin{array}{c}0.63(0.41 \\
0.98) \\
9.04(0.90 \\
90.56)\end{array}$ & & & $\begin{array}{c}0.49(0.28 \\
0.88) \\
0.61(0.01 \\
50.33)\end{array}$ & \\
\hline
\end{tabular}




\begin{tabular}{|c|c|c|c|c|c|c|c|c|c|}
\hline & \multicolumn{3}{|c|}{ SARS-CoV-2 Infection } & \multicolumn{3}{|c|}{ SARS-CoV-2-related Hospitalization } & \multicolumn{3}{|c|}{ SARS-CoV-2-related Mortality } \\
\hline & Base Model $^{\mathrm{a}}$ & $\begin{array}{l}\text { Base-Plus } \\
\text { Models }\end{array}$ & Full Model $^{\mathrm{c}}$ & Base Model $^{\mathrm{a}}$ & $\begin{array}{l}\text { Base-Plus } \\
\text { Models }\end{array}$ & Full Model $^{\mathrm{c}}$ & Base Model $^{\mathrm{a}}$ & $\begin{array}{l}\text { Base-Plus } \\
\text { Models }\end{array}$ & Full Model $^{\mathrm{c}}$ \\
\hline \multicolumn{10}{|l|}{ Housing Type } \\
\hline$\% 1$ unit in structure & & $\begin{array}{l}0.91(0.76 \\
1.10)\end{array}$ & & & $\begin{array}{l}0.52(0.36 \\
\quad 0.74)\end{array}$ & & & $\begin{array}{c}0.78(0.48 \\
1.29)\end{array}$ & \\
\hline$\% \geq 2$ units in structure & & $\begin{array}{c}1.12(0.92 \\
1.36)\end{array}$ & & & $\begin{array}{l}2.08(1.42 \\
\quad 3.04)\end{array}$ & $\begin{array}{l}1.83(1.01 \\
\quad 3.31)\end{array}$ & & $\begin{array}{c}1.31(0.76 \\
2.25)\end{array}$ & \\
\hline$\% \geq 3$ units in structure & & $\begin{array}{l}0.99(0.82 \\
1.21)\end{array}$ & & & $\begin{array}{l}1.43(0.98 \\
2.11)\end{array}$ & & & $\begin{array}{c}1.34(0.77 \\
2.33)\end{array}$ & \\
\hline$\% \geq 5$ units in structure & & $\begin{array}{l}0.92(0.77 \\
1.11)\end{array}$ & & & $\begin{array}{c}0.89(0.62 \\
1.30)\end{array}$ & & & $\begin{array}{l}0.93(0.50 \\
1.73)\end{array}$ & \\
\hline$\% \geq 10$ units in structure & & $\begin{array}{l}0.94(0.78 \\
1.13)\end{array}$ & & & $\begin{array}{l}0.96(0.65 \\
1.40)\end{array}$ & & & $\begin{array}{c}1.08(0.56 \\
2.08)\end{array}$ & \\
\hline$\% \geq 20$ units in structure & & $\begin{array}{l}0.90(0.74 \\
1.09)\end{array}$ & & & $\begin{array}{l}0.83(0.56 \\
1.23)\end{array}$ & & & $\begin{array}{c}0.96(0.48 \\
1.93)\end{array}$ & \\
\hline$\% \geq 50$ units in structure & & $\begin{array}{l}0.85(0.68 \\
1.06)\end{array}$ & & & $\begin{array}{c}0.81(0.51 \\
1.28)\end{array}$ & & & $\begin{array}{c}0.86(0.38 \\
1.95)\end{array}$ & \\
\hline \multicolumn{10}{|l|}{ Transportation } \\
\hline$\%$ commute by walk & & $\begin{array}{c}1.07(0.61 \\
1.89)\end{array}$ & & & $\begin{array}{c}1.40(0.45 \\
4.35)\end{array}$ & & & $\begin{array}{l}0.75(0.17 \\
3.26)\end{array}$ & \\
\hline $\begin{array}{l}\% \text { commute by public } \\
\text { transit }\end{array}$ & & $\begin{array}{c}1.09(0.73 \\
1.62)\end{array}$ & & & $\begin{array}{l}1.97(0.91 \\
\quad 4.25)\end{array}$ & & & $\begin{array}{c}1.69(0.61 \\
4.63)\end{array}$ & \\
\hline$\%$ commute by vehicle & & $\begin{array}{c}1.09(0.78 \\
1.53)\end{array}$ & & & $\begin{array}{l}0.54(0.28 \\
1.03)\end{array}$ & & & $\begin{array}{l}0.93(0.43, \\
2.02)\end{array}$ & \\
\hline$\%$ work from home & & $\begin{array}{c}0.26(0.09 \\
0.75) \\
\end{array}$ & $\begin{array}{c}0.60(0.19 \\
1.90)\end{array}$ & & $\begin{array}{l}1.06(0.14 \\
8.24)\end{array}$ & & & $\begin{array}{c}0.04(0.00 \\
1.47)\end{array}$ & \\
\hline
\end{tabular}

${ }^{a}$ The base model is a logistic mixed model including all individual-level characteristics and the census tract-level per capita testing rate in the Mass General Brigham (MGB) hospital system. Bolded values have a false discovery rate (FDR)-adjusted p-value $<0.05$.

${ }^{\mathrm{b}}$ The base-plus models are a series of logistic mixed models, each including the covariates of the base model with the addition of a single census tract-level variable as a means of examining the effect of that variable in the absence of other, often correlated, census tract-level covariates. Bolded values have an FDR-adjustment of p-values at a level of 0.05 .

${ }^{c}$ The full multivariable model is a logistic mixed model including the covariates of the base model with the addition of all census tract-level variables which met FDR-adjusted significance thresholds in the base-plus models. If several variables within a highly related group (e.g. percent of households with $\geq 5$ members, percent of household with $\geq 6$ members, etc.) each met the FDR-adjusted significance threshold in its respective base-plus model, the variable with the most significant p-value was selected for inclusion in the full, multivariable model.

${ }^{\mathrm{d}}$ Includes reassigned race (based on country of origin or language) for those with recorded Other or Missing race. 
85 excluded due to inconclusive or missing test results

3,665 excluded due to address outside of MA or missing address

76,752 individuals with a MA address and conclusive SARS-CoV-2 PCR test

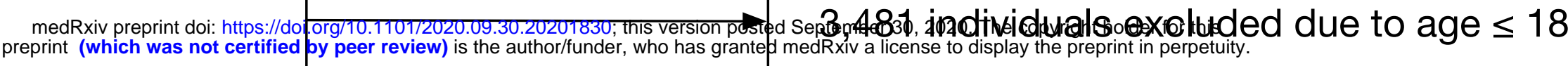

It is made available under a CC-BY 4.0 International license.

15,406 individuals excluded due to employment within the MGB system
57,865 non-MGB-employed adults with a MA address and conclusive SARS-CoV-2 test

Population for Outcome 1 - infection with SARS-CoV-2

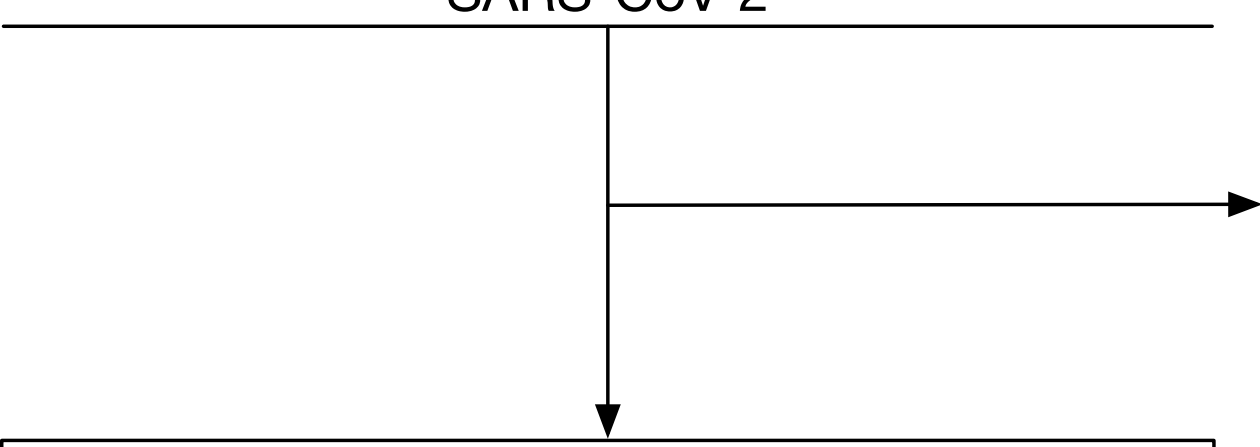

9,839 individuals with a positive SARS-CoV-2 test result

Population for Outcome 2 - inpatient hospitalization related to SARS-CoV-2 among individuals with a positive SARS-CoV-2 test result

3,009 individuals hospitalized due to SARSCoV-2

Population for Outcome 3 - death related to SARS-CoV-2 among individuals hospitalized due to SARS-CoV-2
48,026 individuals excluded due to negative SARS-CoV-2 test result
6,830 individuals excluded due to lack of inpatient record with COVID ICD code or inpatient hospitalization not within 10 days of positive SARS-CoV-2 test result 


\section{A $\quad$ SARS-CoV-2 Outcomes}

- Infection with SARS-CoV-2

- Inpatient hospitalization due to SARS-CoV-2 among infected SARS-CoV-2 patients

- Death related to SARS-CoV-2 among those hospitalized

\section{Model Inputs}

- $\quad$ Base variables (Table 1)

- Individual demographic variables

- Per capita testing

- Census tract level-variables (Table 2, Supplement Table 2)
For each SARS-CoV-2 outcome, select the optimal matern kernel parameters (number of knots and range) for the logistic mixed model by selecting the best model fit using only base variables as covariates (base model). These optimal kernel parameters are used for all subsequent analysis. All other kernel parameters are set to default.

$\mathrm{D}$

For each SARS-CoV-2 outcome, loop through all Census tract-level variables and fit a logistic mixed model using all base variables plus that particular Census variable (base-plus model). Aggregate the statistics for all census variables into a single data frame.

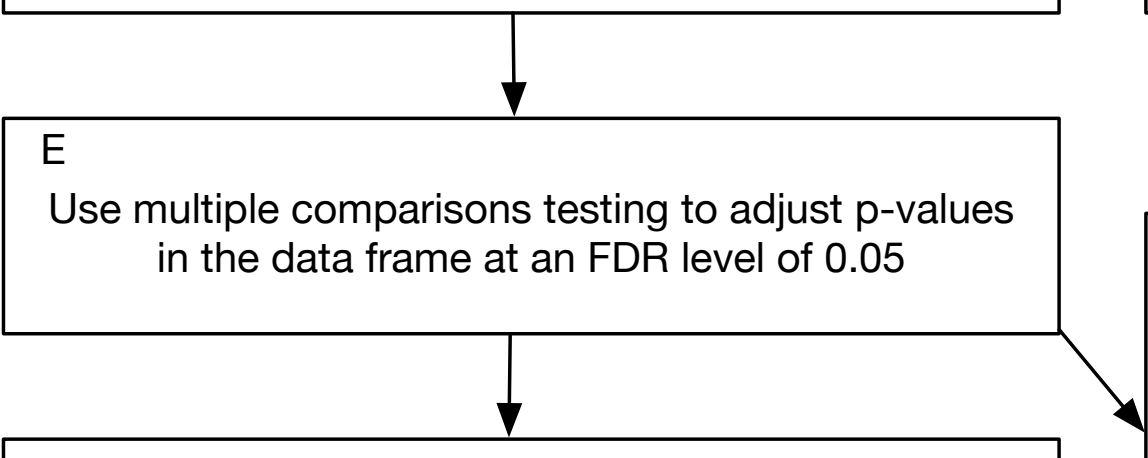

$\mathrm{F}$

Remove all census variables with adjusted $p$-value greater than 0.05 from subsequent analysis
$\mathrm{H}$

For each SARS-CoV-2 outcome, report base and area level census variables in the multivariate model with $p$ value $<0.05$

G

Run a multivariate logistic mixed model with base variables and all census variables with an adjusted $p$ value less than 0.05 (full model). If there is a cluster of similar variables (e.g. percent of households with $\geq 5$ people, percent of people with $\geq 6$ people, etc...) then select the variable with the most significant $p$-value. 
